УДК 355.25:371.132 (477)

DOI:

Наталія Тробюк, викладач кафедри психологї та педагогіки, Національна академія Національної гвардії України Володимир Дем'янишин, кандидат педагогічних наук, старший викладач кафедри автобронетанкової техніки, Національна академія Національної гвардії України Ольга Александрова, викладач кафедри фізичного виховання та спорту, Харківський національний університет імені В.Н. Каразіна

Володимир Гончар, начальник мовного відділу, Національна академія Наџіональної гвардї Украӥни

\title{
ФОРМУВАННЯ ТОЛЕРАНТНОСТІ У МАЙБУТНІХ ОФІЦЕРІВ НАЦІОНАЛЬНОЇ ГВАРДІЇ УКРАЇНИ ЯК НАУКОВО-ПЕДАГОГІЧНА ПРОБЛЕМА
}

У статті на підставі проведеного аналізу наукової літератури та нормативно-правових актів (зокрема законів Украӥни “Про Національнугвардію України” та "Про Статут внутрішньої служби Збройних Сил України”) визначено необхідність формування толерантності у майбутніх офіцерів Національної гвардії України та запропоновано таке ї̈ визначення: толерантність офічера Національної гвардї України проявлення або пригнічення на підставі вимог нормативно-правових актів терпимості до різних поглядів, норм поведінки, звичок особи, групи осіб з якими офіцер здійснює комунікації у процесі службово-бойової діяльності.

Ключові слова: толерантність; майбутні офіџери; Начіональна гвардія Украӥни; вищі військові навчальні заклади.

Табл. 1. Літ. 18.

Nataliya Trobyuk, Lecturer of the Psychology and Pedagogy Department, National Academy of the National Guard of Ukraine Volodymyr Demyanyshyn, Ph.D.(Pedagogy), Senior Lecturer of the Auto Armored Vehicles Department, National Academy of the National Guard of Ukraine Olha Alexandrova, Lecturer of the Physical Education and Sports Department, Kharkiv V. N. Karazin National University Volodymyr Honchar, Head of the Language Department, National Academy of the National Guard of Ukraine

\section{THE FORMATION OF TOLERANCE IN FUTURE OFFICERS OF THE NATIONAL GUARD OF UKRAINE AS A SCIENTIFIC AND PEDAGOGICAL PROBLEM}

The process of forming tolerance has been addressed in many papers, however, the need to build tolerance in future officers of the National Guard of Ukraine and its essence has not been determined yet. Such a need remains controversial. The presence of such a quality in the officer as a tolerance can both help and interfere with the performance of combat missions by a serviceman.

The purpose of the article is to determine the necessity of forming tolerance in future officers of the National Guard of Ukraine and its essence.

The activities of the National Guard of Ukraine are prohibit the use of torture or other cruel, inhuman or degrading treatment or punishment. In essence, it is a principle of tolerance in the activities of the National Guard of Ukraine, which are reflected in the Declaration approved by resolution 5.61 of the UNESCO General Conference of 16.11.1995.

To formulate the concept "tolerance of an officer of the National Guard of Ukraine", a list of persons, groups of persons with whom the officer communicates in the course of military service, norms of the officer's behavior towards these persons, groups of persons reflected in the laws of Ukraine "About the National Guard of Ukraine" and About the Statute of the Internal Service of the Armed Forces of Ukraine.

It is impossible to speak about the manifestation of tolerance towards representatives of illegal militarized or armed formations (groups), terrorist organizations, organized groups and criminal organizations. Due to the variety of tasks of the National Guard of Ukraine in comparison with the Armed Forces of Ukraine, the military formation under study makes it special, requires especially more difficult training of future officers, in the process of which it is necessary not only to form and develop such quality as tolerance, but also to teach them to regulate their emotional states.

(c) Н. Тробюк, В. Дем'янишин, 


\section{ФОРМУВАННЯ ТОЛЕРАНТНОСТІ У МАЙБУТНІХ ОФІЦЕРІВ НАЦІОНАЛЬНОЇ ГВАРДІЇ УКРАЇНИ ЯК НАУКОВО-ПЕДАГОГІЧНА ПРОБЛЕМА}

On the basis of the analysis of scientific literature and normative legal acts, the necessity of forming tolerance in future officers of the National Guard of Ukraine is determined and its definition is proposed: tolerance of an officer of the National Guard of Ukraine - manifestation or suppression on the basis of the requirements of normative legal acts of tolerance to different views, norms of behavior, habits of a person, a group of persons with whom the officer communicates in the course of military service.

Keywords: tolerance; future officers; the National Guard of Ukraine; higher military educational establishments.

П

остановка проблеми. Представники військових формувань та правоохоронних органів виконують службово-бойові завдання у міжнародних миротворчих операціях. За результатами проведених опитувань цих категорій осіб установлено наявність загрози виникнення конфліктів між військовослужбовцями представниками різних держав-учасниць Організації Об'єднаних Націй (ООН). Основними причинами виникнення таких конфліктів $є$ : відсутність у військовослужбовців знань про етичні норми поведінки і культуру народів, представники яких беруть участь у миротворчих операціях, та держави, на території якої проводиться сама операція; гендерна нерівність, до якої ставлення у різних країнах неоднакове, а також недостатній рівень підготовки військовослужбовця з питань міжкультурної комунікації. Загрози виникнення конфліктів між військовослужбовцями у певних умовах можуть перерости у небезпеку. Це явище особливо небезпечне під час виконання службовобойових завдань і може призвести до таких наслідків, як: невиконання службово-бойових завдань; втрата особового складу миротворчого підрозділу; підрив репутації місії та державучасниць, від яких сформовані миротворчі підрозділи; депортація особового складу миротворчих підрозділів [6,71].

У вирішенні подібних до описаних проблем важливе місце займає система підготовки кадрів для військових формувань та правоохоронних органів України, зокрема відведенню в ній важливого місця - формуванню такої необхідної якості у майбутніх офіцерів як толерантність.

Аналіз останніх досліджень і публікацій. Формуванню та розвитку готовності майбутніх офіцерів до службово-бойової діяльності, зокрема до управління своїми підрозділами посвячені немало праць. Їх можна розділи за етапами професійного становлення військовослужбовця [4, 316] професійного самовизначення щодо проходження військової служби [5], адаптації до службово-бойової та освітньої діяльностей [12], формуванні та удосконалювання необхідних компетентностей для організації службовобойової діяльності [7; 8]. Щодо праць присвячених формуванню толерантності у майбутніх офіцерів Національної гвардії України - іх небагато [6; 7].
А ті які $€-$ не повністю вирішують зазначену проблему.

Ученими М.М. Медвідем та Я.В. Павловим виявлено особливості міжкультурного конфлікту, який формується між військовослужбовцями під час виконання службово-бойових завдань у міжнародних миротворчих операціях та визначено шляхи удосконалення системи професійної підготовки військових формувань, направлених на запобігання та ліквідації конфліктів між військовослужбовцями, які беруть участь у міжнародних миротворчих операціях [6;7].

На думку психологів, для визначення рівня толерантності військовослужбовця доцільно проводити діагностику, використовуючи серед існуючих методик такі, як: експрес-питальник “Індекс толерантності” (автори - Г.У. Солдатова, О.А. Кравцова, О.Е. Хухлаєв, Л.А. Шайгерова); питальник для вимірювання толерантності (автори - В.С. Магун, М.С. Жамкочьян, М.М. Магура); шкалу фашизму (автори: Т. Адорно, Е. ФренкельБрунсвік, Д. Левінсон, Р. Сенфорд).

Процес формування толерантності досліджували такі учені у галузі педагогічних наук як М.В. Андрєєв [1], Ю.В. Ірхіна [3], О.В. Орловська [9], Н.С. Тимченко [14] та інші. Проте перш ніж розглядати його слід визначити необхідність формування толерантності у майбутніх офіцерів Національної гвардії України та іiі сутність.

Адже, насправді така необхідність залишається суперечливою. Наявність такої якості як толерантність у офіцера може як допомагати так і заважати у виконанні службовобойових завдань військовослужбовцем.

Мета статті - визначити необхідність формування толерантності у майбутніх офіцерів Національної гвардії України та іiі сутність.

Виклад основного матеріалу. Слово “толерантний” тлумачиться як здатний переносити несприятливий вплив яких-небудь факторів; поблажливий, терпимий до чиїхось думок, поглядів, вірувань тощо [15, 595]. У словнику із суспільних наук знайомимося з більш чітким визначенням:

- толерантність (лат. tolerantia - терпіння) - 1) терпимість до різних поглядів, норм поведінки, звичок, відмінних від тих, котрі розділяє суб'єкт; відкритість для будь-яких ідейних течій, 


\section{ФОРМУВАННЯ ТОЛЕРАНТНОСТІУ МАЙБУТНІХ ОФІЦЕРІВ НАЦІОНАЛЬНОӤ ГВАРДІЇ УКРӒ̈НИ ЯК НАУКОВО-ПЕДАГОГІЧНА ПРОБЛЕМА}

відсутність страху перед конкуренцією ідей; 2) у психології: повна або часткова відсутність реагування на який-небудь несприятливий фактор у результаті зниження чутливості до його впливу [13, 372, 373].

У дослідженні О. В. Орловської “толерантність визначено як інтегративну якість особистості, що відображає активну моральну позицію і готовність до конструктивної взаємодії $з$ людьми і групами незалежно від їх національної, соціальної, релігійної, гендерної приналежності, поглядів, світогляду, стилю мислення й типу поведінки (виключаючи асоціальні прояви свідомості і поведінки); сприяє успішному самоствердженню особистості та іiі самореалізації у суспільстві” $[9,9]$.

Відповідно до ст. 3 Закону України “Про Національну гвардію України” визначено, що діяльність Національної гвардії України грунтується на принципах верховенства права, забезпечення дотримання прав і свобод людини і громадянина, позапартійності, безперервності, законності, відкритості для демократичного цивільного контролю, прозорості, відповідальності, централізованого керівництва та єдиноначальності. У діяльності Національної гвардії України забороняється застосування тортур, катувань та інших жорстких, нелюдських або таких, що принижують гідність, видів поводження та покарання $[10,3]$. По суті мова йде про принцип толерантності в діяльності Національної гвардії України.

Принципи толерантності відображені у Декларації, затверджена резолюцією 5.61 Генеральной конференции ЮНЕСКО від 16.11 .1995 [2]. В згаданому документі звертається увага на те, що “толерантність $є$ не тільки важливим принципом, але й необхідною умовою миру і соціально-економічного розвитку всіх народів" [2]. Також зазначається, що формування толерантності у здобувачів $\epsilon$ обов'язковим в освітньому процесі: “Виховання в дусі толерантності слід розглядати як невідкладний імператив. У зв'язку з цим необхідно заохочувати методи систематичного i раціонального навчання толерантності, які розкривають культурні, соціальні, економічні, політичні та релігійні джерела нетерпимості, що лежать в основі насильства і відчуження. Політика і програми в області освіти повинні сприяти поліпшенню взаємопорозумінню, зміцненню солідарності і терпимості у відносинах як між окремими людьми, так і між етнічними, соціальними, культурними, релігійними і мовними групами, а також націями [2, ст. 4].

У такому випадку для того щоб визначити що таке "толерантність офіцера Національної гвардії України” необхідно визначити перелік осіб, груп осіб з якими офіцер здійснює комунікації у процесі службово-бойової діяльності, норми поведінки офіцера до цих осіб, груп осіб, визначені законами України “Про Національну гвардію України" [10] та "Про Статут внутрішньої служби Збройних Сил України” [11]. Результат реалізації вище описаного відображено у таблиці 1.

Звісно, що про прояв толерантності до представників незаконних воєнізованих або збройних формувань (груп), терористичних організацій, організованих груп та злочинних організацій мова не може вестись. Завдяки різноманіття завдань Національної гвардії України у порівнянні зі Збройними Силами України, досліджуване військове формування робить особливим, вимагає особливої складнішої підготовки майбутніх офіцерів, у процесі якої $є$ необхідним не лише формувати та розвивати таку якість як толерантність, а й навчити їх регулювати свої емоційні стани.

На підставі проведеного аналізу наукової літератури та нормативно-правових актів нами запропоновано розуміти під толерантністю офіцера Національної гвардї̈ України проявлення або пригнічення на підставі вимог нормативно-правових актів терпимості до різних поглядів, норм поведінки, звичок особи, групи осіб 3 якими офіцер здійснює комунікації у процесі службово-бойової діяльності.

Наоснові вивчення науковихпідходівО.В.Орловською визначено сутність поняття "толерантне освітнє середовище", що по трактоване як “педагогічна умова, яка забезпечує атмосферу не насильства, безпечної суб'єкт-суб'єктної взаємодії, демократичний стиль педагогічного управління, психолого-педагогічну підтримку та врахування позитивного досвіду учнів на основі довіри, поваги, терпіння, толерантного ставлення, а також сприяє ефективності та успішності навчання і виховання толерантної особистості” [9, 9]. До педагогічних умов формування толерантності на думку М.В. Андрєєва слід віднести “створення позитивного емоційно-психологічного мікроклімату, що залежить від узгодженості взаємодій, ситуацій успіху, конструктивного вирішення конфліктних ситуацій; встановлення партнерських взаємовідносин та атмосфери довіри між усіма суб'єктами педагогічного процесу" $[1,4]$. Погоджуємось 3 обгрунтованими думками вчених, проте враховуючи особливість підготовки військових фахівців, у подальшому доцільно на підставі думок експертів у військовій сфері визначити педагогічні умови формування 


\section{ФОРМУВАННЯ ТОЛЕРАНТНОСТІУ МАЙБУТНІХ ОФІЦЕРІВ НАЦІОНАЛЬНОЇ ГВАРДІЇ УКРАЇНИ ЯК НАУКОВО-ПЕДАГОГІЧНА ПРОБЛЕМА}

\begin{tabular}{|c|c|c|c|}
\hline \multicolumn{4}{|c|}{$\begin{array}{c}\text { Визначення поняття “толерантність офіцера Національної гвардії України” шляхом } \\
\text { анлізу його елементів }\end{array}$} \\
\hline $\begin{array}{c}\text { Особи, групи осіб з якими } \\
\text { офіцер здійснює комунікації } \\
\text { у процесі службово-бойової } \\
\text { діяльності }\end{array}$ & $\begin{array}{c}\text { Норми поведінки офіцера до ососби, } \\
\text { групи осіб, визначені нормативно- } \\
\text { правовими актами }\end{array}$ & $\begin{array}{l}\text { Доцільно } \\
\text { проявляти } \\
\text { толе- } \\
\text { рантність }\end{array}$ & $\begin{array}{c}\text { Доцільно } \\
\text { пригнічувати } \\
\text { толе- } \\
\text { рантність }\end{array}$ \\
\hline Громадяни & $\begin{array}{l}\text {... виконання завдань із захисту та } \\
\text { охорони життя, прав, свобод і законних } \\
\text { інтересів громадян }[10, \text { ст. } 1]\end{array}$ & + & - \\
\hline $\begin{array}{c}\text { Представники } \\
\text { правоохоронних органів }\end{array}$ & $\begin{array}{l}\text {... у взаємодії } 3 \text { правоохоронними } \\
\text { органами - із забезпечення державної } \\
\text { безпеки і захисту державного кордону } \\
{[10, \text { ст. } 1]}\end{array}$ & + & - \\
\hline $\begin{array}{c}\text { Представники Збройних Сил } \\
\text { України }\end{array}$ & $\begin{array}{l}\text {.. бере участь відповідно до закону у } \\
\text { взаємодії зі Збройними Силами України } \\
\text { у відсічі збройній агресії проти України } \\
\text { та ліквідації збройного конфлікту } \\
\text { шляхом ведення воєнних (бойових) дій, } \\
\text { a також у виконанні завдань } \\
\text { територіальної оборони }[10, \text { ст. } 1]\end{array}$ & + & - \\
\hline $\begin{array}{c}\text { Представники незаконних } \\
\text { воєнізованих або збройних } \\
\text { формувань (груп), } \\
\text { терористичних організацій, } \\
\text { організованих груп та } \\
\text { злочинних організацій }\end{array}$ & 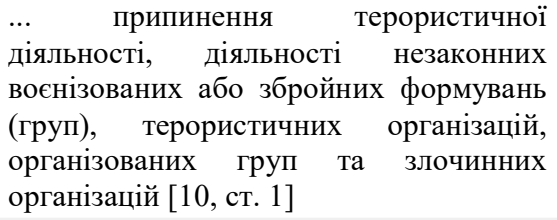 & - & + \\
\hline $\begin{array}{c}\text { Представники } \\
\text { дипломатичних } \\
\text { представництв, консульських } \\
\text { установ іноземних держав, } \\
\text { міжнародних організацій }\end{array}$ & $\begin{array}{l}\text {... охорона дипломатичних } \\
\text { представництв, консульських установ } \\
\text { іноземних держав, представництв } \\
\text { міжнародних організацій в Україні [10, } \\
\text { ст. 2] }\end{array}$ & + & - \\
\hline $\begin{array}{l}\text { Особи, узяті під варту, } \\
\text { засуджені }\end{array}$ & $\begin{array}{l}\text {... участь у припиненні групових } \\
\text { протиправних дій осіб, узятих під } \\
\text { варту, засуджених, а також ліквідації } \\
\text { наслідків таких дій в установах } \\
\text { попереднього ув'язнення, виконання } \\
\text { покарань [10, ст. 2] }\end{array}$ & + & + \\
\hline $\begin{array}{c}\text { Представники складу } \\
\text { національного персоналу або } \\
\text { національного контингенту }\end{array}$ & $\begin{array}{l}\text {... можуть залучатися до участі в } \\
\text { міжнародних операціях } 3 \text { підтримання } \\
\text { миру і безпеки у складі національного } \\
\text { персоналу або } \\
\text { контингенту }[10, \text { ст. 2] }\end{array}$ & + & - \\
\hline Командири (начальники) & $\begin{array}{l}\text {... постійно виховувати підлеглих у дусі } \\
\text { гуманізму та людяності, спираючись } \\
\text { при цьому на загальновизнані } \\
\text { принципи міжнародного права ... [11, } \\
\text { ст. 59] }\end{array}$ & + & - \\
\hline Підлеглі & $\begin{array}{l}\text {... беззастережно виконувати накази } \\
\text { командирів (начальників) і захищати їх } \\
\text { у бою ... [11, ст. } 11]\end{array}$ & + & - \\
\hline
\end{tabular}

толерантності у майбутніх офіцерів Національної гвардії України.

Висновки 3 даного дослідження і перспективи подальших розвідок. На підставі проведеного аналізу наукової літератури та нормативно-правових актів визначено необхідність формування толерантності у майбутніх офіцерів Національної гвардії України

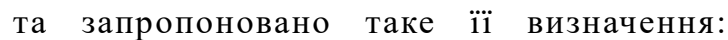
толерантність офіцера Національної гвардії України - проявлення або пригнічення на підставі вимог нормативно-правових актів терпимості до 


\section{ФОРМУВАННЯ ТОЛЕРАНТНОСТІУ МАЙБУТНІХ ОФІЦЕРІВ НАЦІОНАЛЬНОЇ ГВАРДІЇ УКРАЇНИ ЯК НАУКОВО-ПЕДАГОГІЧНА ПРОБЛЕМА}

різних поглядів, норм поведінки, звичок особи, групи осіб з якими офіцер здійснює комунікації у процесі службово-бойової діяльності.

Перспективи подальших розвідок дослідження вбачаємо в проведені опитування здобувачів вищої освіти - майбутніх офіцерів (які навчаються на тактичному рівні військової освіти) та офіцерів, які мають певний досвід службово-бойової діяльності, брали участь у виконанні різних завдань Національної гвардії України (які навчаються на оперативно-тактичному рівні військової освіти). Дані опитувальники за структурою будуть схожими й дадуть можливість отримати наступну інформацію: чи поділяють здобувачі вищої освіти 3 авторами статті думку про необхідність формування толерантності у майбутніх офіцерів Національної гвардії України; приклади того як наявність толерантності допомагає або заважає виконанню службовобойових завдань військовослужбовцем; які педагогічні умови повинні бути створені у вищому військовому навчальному закладі для формування та розвитку толерантності у майбутніх офіцерів Національної гвардії України та для навчання регулювання своїми емоційними станами у процесі виконанні службово-бойових завдань.

\section{ЛІТЕРАТУРА}

1. Андрєєв М. В. Формування толерантності вчителя загальноосвітньої школи: автореф. дис... канд. пед. наук: 13.00 .04 ; Харк. нац. пед. ун-т ім. Г.С.Сковороди. Харків, 2009. 23 с.

2. Декларація принципів толерантності : від 16.11.1995 № 995_503. URL : https:// zakon.rada.gov.ua/laws/show/995_503 (дата звернення : 28.06.2019)

3. Ірхіна Ю. В. Формування професійної толерантності майбутніх викладачів вищої школи: автореф. дис. ... канд. пед. наук: 13.00.04 ; Південноукр. нац. пед. ун-т ім. К.Д. Ушинського. Одеса, 2011. $20 \mathrm{c}$.

4. Медвідь М. М. Методологія формування і розвитку людських ресурсів для використання у службово-бойовій діяльності: дис. д-ра економ. наук. Харків, 2015. 577 с.

5. Медвідь М. М., Бабічев А. В., Дем'янишин В. М., Медвідь Ю. І., Бухун А. Г. Попереду змін у військових системах вищої освіти та професійної орієнтації. Вісник Черкаського університету. Серія : Педагогічні науки. 2016. № 14. С. 7687.

6. Медвідь М. М., Павлов Я. В. Обгрунтування необхідності підготовки консультантів з питань міжкультурної комунікації та удосконалення системи професійної підготовки військових формувань. Теорія та методика навчання та виховання. 2013. Вип. 34. С. 70-79.

7. Медвідь М. М., Павлов Я. В. Підхід до визначення компетенцій та умов до формування відповідних компентентностей успішної миротворчої діяльності. Військова освіта: Збірник наукових праць Національного університету оборони. 2016. № 1 (33). С. 185194.

8. Медвідь М. М., Павлов Я. В., Медвідь Ю. І., ТробюкН. Ю., Дем'янишин В. М., Александрова О. А. Шляхи формування тарозвитку готовності офіцерів до управління їх підрозділами в умовах сумісного виконання завдань 3 підрозділами країн-партнерів України. Вісник Черкаського університету. Серія : Педагогічні науки. 2018. № 14. С. 4552.

9. Орловська О. В. Підготовка майбутнього вчителя до виховання толерантності в учнів старшої школи США: автореф. дис. ... канд. пед. наук : 13.00.04 ; НАПН України ; Ін-т пед. освіти і освіти дорослих. К., 2011. 20 с.

10. Про Національну гвардію України : Закон України від 13.03.2014 № 876-VII. URL : https:// zakon.rada.gov.ua/laws/show/876-18 (дата звернення: 28.06.2019)

11. Про Статут внутрішньої служби Збройних Сил України : Закон України від 24.03.1999 № 548XIV. URL: https://zakon.rada.gov.ua/laws/show/54814 (дата звернення : 28.06.2019)

12. Сергиенко Т. Н., Медвидь М. М., Рютин В. В. Модель социальнопедагогической профилактики дезадаптации курсантов младших курсов высших военных учебных заведений и анализ результатов эксперимента по ее внедрению. Wschonioeuropejskie Czasopismo Naukowe. 2018. № 3 (31), 5. С. 29-39.

13. Сучасний словник із суспільних наук / За ред. О. Г. Данильяна, М. І. Панова. Харків: Прапор, 2006. 432 с.

14. Тимченко Н. С. Формування професійноетичних якостей майбутніх службовців-митників: Автореф. дис... канд. пед. наук: 13.00 .04 ; Центр. ін-т післядиплом. пед. освіти АПН України. К., 2003. $20 \mathrm{c}$.

15. Тлумачний словник української мови / Укладачі Корольова Т. В., Коврига Л. П. Харків: Синтекс, 2002. 672 c.

\section{REFERENCES}

1. Andreev, M.V. (2009). Formuvannia tolerantnosti vchytelia zahalnoosvitnoi shkoly [Formation of teacher tolerance in secondary school]. Extended abstract of candidate's thesis. Kharkiv, 23 p.[in Ukrainian].

2. Deklaratsiia pryntsypiv tolerantnosti: 


\section{ФОРМУВАННЯ ТОЛЕРАНТНОСТІУ МАЙБУТНІХ ОФІЦЕРІВ НАЦІОНАЛЬНОЇ ГВАРДІЇ УКРАЇНИ ЯК НАУКОВО-ПЕДАГОГІЧНА ПРОБЛЕМА}

vid 16.11.1995 № 995_503 [The declaration of principles of tolerance: 16.11.1995 № 995_503]. Available at: https://zakon.rada.gov.ua/laws/show/ 995_503 (accessed: 28 June 2019)[in Ukrainian].

3. Irhina, Yu. V. (2011). Formuvannia profesiinoi tolerantnosti maibutnikh vykladachiv vyshchoi shkoly [Formation of professional tolerance of future high school teachers]. Extended abstract of candidate's thesis. South Ukrainian. nat. ped. them. K.D. Ushinsky. Odesa. 20 p.[in Ukrainian].

4. Medvid, M. (2015). Metodolohiia formuvannia i rozvytku liudskykh resursiv dlia vykorystannia u sluzhbovo-boiovii diialnosti [Methodology of formation and development of human resources for use in servicecombat activity]. Doctor's thesis. Kharkiv, 577 p. [in Ukrainian].

5. Medvid, M., Babichev, A., Demyanyshyn, V., Medvid, Yu. \& Bukhun, A. (2016). Poperedu zmin u viiskovykh systemakh vyshchoi osvity ta profesiinoi oriientatsii [Ahead of changes in military systems of higher education and professional orientation]. Bulletin of the Cherkasy University. Serial Pedagogical sciences. 14. pp.76-87. [in Ukrainian].

6. Medvid, M.M. \& Pavlov, Ya.V. (2013). Obgruntuvannia neobkhidnosti pidhotovky konsultantiv z pytan mizhkulturnoi komunikatsii ta udoskonalennia systemy profesiinoi pidhotovky viiskovykh formuvan [The substantiation of necessity of training of consultants on questions of the intercultural communication and improvement of the system of professional training of military formations]. Theory and methodology of teaching and upbringing. Vol. 34. pp. 70-79. [in Ukrainian].

7. Medvid, M.M. \& Pavlov, Ya.V. (2016). Pidkhid do vyznachennia kompetentsii ta umov do formuvannia vidpovidnykh kompententnostei uspishnoi myrotvorchoi diialnosti [Approach to definition of competencies and conditions for formation of corresponding competencies of successful peacekeeping activity]. Military Education: A Collection of Scientific Papers of the National Defense University. No. 1 (33). pp. 185-194. [in Ukrainian].

8. Medvid, M.M., Pavlov Ya.V., Medvid, Yu.I., Trobyuk, N. Yu., Demianyshyn, V.M. \& Aleksandrova, O.A. (2018). Shliakhy formuvannia ta rozvytku hotovnosti ofitseriv do upravlinnia yikh pidrozdilamy v umovakh sumisnoho vykonannia zavdan z pidrozdilamy krain-partneriv Ukrainy [Ways of formation and development of officers' readiness to manage their units in conditions for joint implementation of tasks with the units of partner countries of Ukraine]. Bulletin of Cherkasy University. Series: Pedagogical Sciences. No. 14. pp. 45-52. [in Ukrainian].

9. Orlovska, O.V. (2011). Pidhotovka maibutnoho vchytelia do vykhovannia tolerantnosti v uchniv starshoi shkoly SShA [Preparing a Future Teacher for Educating Tolerance in the US High School Students]. Extended abstract of candidate's thesis. Kyiv, 20 p. [in Ukrainian].

10. Pro Natsionalnu hvardiiu Ukrainy : Zakon Ukrainy vid 13.03.2014 № 876-VII. [About the National Guard of Ukraine: Law of Ukraine of 13.03.2014 No. 876-VII]. Available at: https:// zakon.rada.gov.ua/laws/show/876-18 (accessed: 28 June 2019) [in Ukrainian].

11. Pro Statut vnutrishnoi sluzhby Zbroinykh Syl Ukrainy : Zakon Ukrainy vid 24.03.1999 № 548XIV. [About the Statute of the Internal Service of the Armed Forces of Ukraine: Law of Ukraine of March 24, 1999 No. 548-XIV]. Available at: https: // zakon.rada.gov.ua/laws/show/548-14 (accessed: 28 June 2019) [in Ukrainian].

12. Sergienko, T., Medvid, M. \& Ryutin, V. (2018). Model sotsialnopedagogicheskoy profilaktiki dezadaptatsii kursantov mladshikh kursov vysshikh voennykh uchebnykh zavedeniy i analiz rezultatov eksperimenta po ee vnedreniyu [Model of sociopedagogical prevention of maladaptation of younger cadets of higher military educational institutions and analysis of the results of the experiment on its introduction]. Wschonioeuropejskie Czasopismo Naukowe [Eastern European scientific journal]. No.3 (31). pp. 29-39. [in Russian].

13. Suchasnyi slovnyk iz suspilnykh nauk (2006). [Modern Dictionary of Social Sciences]. (Ed.). O. G. Danilian, M. I. Panova. Kharkiv, 432 p. [in Ukrainian].

14. Timchenko, N.S. (2003). Formuvannia profesiino-etychnykh yakostei maibutnikh sluzhbovtsiv-mytnykiv [Formation of professional and ethical qualities of future customs officers]. Extended abstract of candidate's thesis. Center. institute postgraduate degree. ped. education of APS of Ukraine. Kyiv, 20 p. [in Ukrainian].

15. Tlumachnyi slovnyk ukrainskoi movy (2002). [Interpretive Dictionary of the Ukrainian Language]. Compilers Korolova T.V., Kovryga L.P. Kharkiv, 672 p. [in Ukrainian].

Стаття надійшла до редакції 06.08.2019

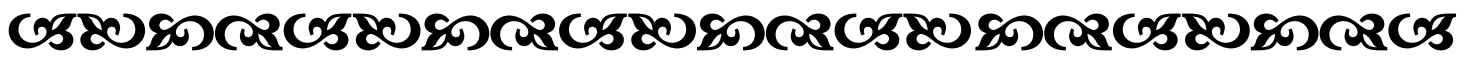

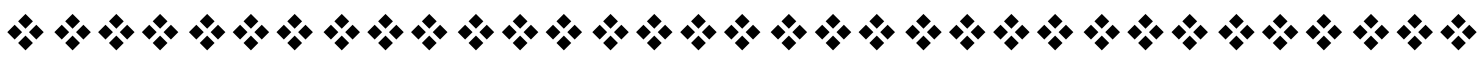

